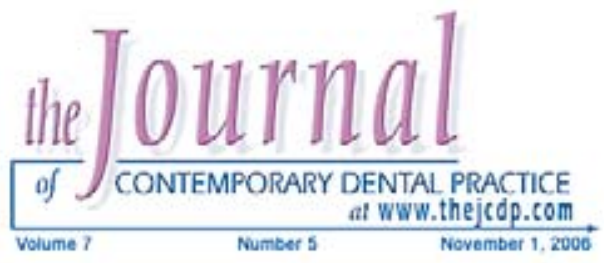

\title{
Providing Advanced Degrees in Dental Hygiene via Computer Mediated Distance Learning: A Model Program
}

\author{
Kimberly S. Krust Bray, RDH, MS; \\ Cynthia C. Gadbury-Amyot, BSDH, EdD; \\ Tanya Villalpando Mitchell, RDH, MS
}

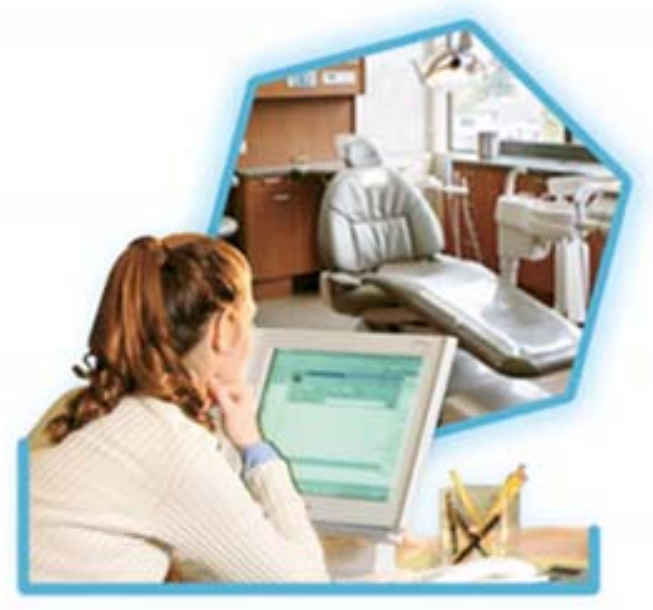

Abstract

A chief concern regarding distance education for the health professions is quality of the experience. Distance education has the potential for expanding student access, providing individualized instruction, and promoting active learning among geographically separated members of learning groups. Students and professors who have participated in distance learning platforms have expressed concerns about technical problems, inability to interact in real time with each other, and other frustrations related to this type of delivery. The Dental Hygiene program at the University of Missouri-Kansas City (UMKC) has addressed these issues and enhanced an already successful program by putting the professor, a technologist, and the student in the same space, at the same time, in real time. This enhancement has substantiated the ability of distance education to provide instruction among geographically separated members of learning groups, making it a plausible solution to the shortage of educators in healthcare professions.

Keywords: Distance education, online learning, computer assisted instruction, dental hygiene

Citation: Bray KSK, Gadbury-Amyot CC, Mitchell TV. Providing Advanced Degrees in Dental Hygiene via Computer Mediated Distance Learning: A Model Program. J Contemp Dent Pract 2006 November;(7)5:096-107.

(c) Seer Publishing 


\section{Introduction}

The information era creates many opportunities as well as challenges for education. Today's postsecondary student is likely to have as much or more experience and greater expectations for the use of technology than perhaps their faculty. In order to meet these demands, many educators have embraced the computer-mediated ability to provide instruction. Other faculties have responded with uncertainty, resistance, or confusion. ${ }^{1}$ Not only is computer technology increasingly used to support traditional course offerings but also as a means to deliver distance learning programs. Advancements in computer technology and its adaptation to education are significant developments in the evolution of distance education. Simply put, distance education is planned learning that occurs in a different place from the teaching. ${ }^{2}$ Regardless of the configuration, a classroom is still a teacher and learners. While faculty and administrators continue to debate the virtues and shortcomings, distance education is on the rise.
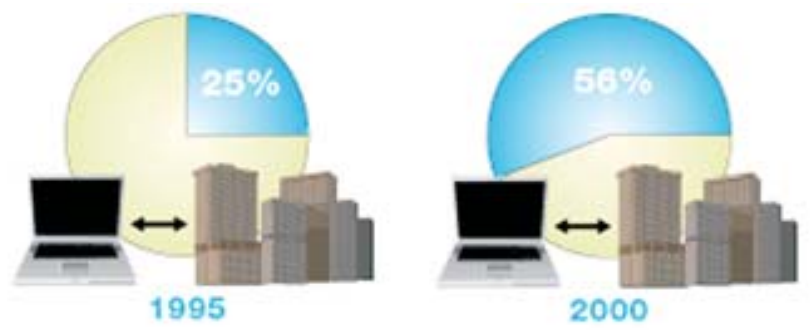

Distance learning can take many forms and has evolved significantly from early correspondence distribution to Internet assisted and video streaming delivery. Asynchronous instruction allows faculty the ability to present course content at a time and site convenient to the student. ${ }^{3}$ While only $25 \%$ of higher education institutions offered distance education courses in 1995 , this proportion increased to $56 \%$ in 2000.3 In 2000-2001 the number of institutions offering degree programs designed to be completed entirely through distance education was only $19 \%$. The number of such programs in healthcare professions alone is unknown. Most of this growth was in courses at post-secondary institutions using asynchronous computerbased technology as compared to video-based technology (two-way video). ${ }^{4}$ While many faculty, institutions, and students are already experienced in distance delivery, those newly evaluating the concept may be unsure what to expect when planning or enrolling in a course online.

\section{Rationale For Distance Education}

Distance education has the potential for expanding student access, providing individualized instruction, and promoting active learning among geographically separated members of learning groups. ${ }^{5}$ A systematic review of articles describing faculty comparisons between teaching computermediated instruction and traditional teaching revealed advantages and short comings in terms of faculty workload, access to education, adapting to technology, and instructional quality (Table 1). Many of the advantages of distance learning are countered by concomitant challenges. The technology allows for increased connectivity and instantaneous responses which can increase the communications workload for the course director and students alike. The most successful delivery makes use of a blended model combining technologies to provide both constant access to course materials and face-to-face interactions with content experts. ${ }^{6}$ The collective experiences of faculty show planning, content preparation and presentation, scheduling, course design, instructional technologies, and other activities are all affected to varying degrees when teaching via distance.

\section{Distance Education For Healthcare Professions} There continues to be debate regarding the suitability of distance education for healthcare disciplines. A chief concern regarding distance education for the health professions is quality of the experience. Such programs will be judged and must maintain the same standards of excellence and competency achieved by traditional education. Nursing program outcomes mirror those from other disciplines reporting no significant differences in academic achievement when distance learning courses are compared with traditional on-campus courses. $^{7-8}$

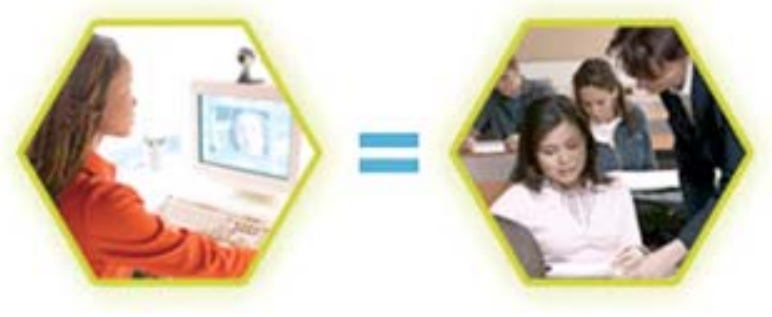


Table 1. Faculty experiences with distance education.

\begin{tabular}{|c|c|c|c|c|}
\hline & Faculty Workload & Access to Education & $\begin{array}{l}\text { Adapting to } \\
\text { Technology }\end{array}$ & Instructional Quality \\
\hline Advantages & $\begin{array}{l}\text { Efficient course } \\
\text { management } \\
\text { Rapid messaging } \\
\text { (email) }\end{array}$ & $\begin{array}{l}\text { Constant access to } \\
\text { course materials } \\
\uparrow \text { Interaction } \\
\text { More diverse and/or } \\
\text { engaging } \\
\text { conversations }\end{array}$ & Record of exchanges & $\begin{array}{l}\uparrow \text { Collaborative } \\
\text { learning } \\
\text { Communication } \\
\text { outside the classroom } \\
\text { Autonomy } \\
\text { Provide individualized } \\
\text { attention }\end{array}$ \\
\hline Disadvantages & $\begin{array}{l}\uparrow \text { Volume of } \\
\text { communication } \\
\text { Redesign of course } \\
\text { materials } \\
\text { More instructor control }\end{array}$ & $\begin{array}{l}\text { Need to supplement } \\
\text { with synchronous } \\
\text { communication } \\
\text { Scheduling in } \\
\text { different time zones } \\
\text { Tracking } \\
\text { asynchronous } \\
\text { student progress }\end{array}$ & $\begin{array}{l}\text { Lack of support for } \\
\text { student/faculty use of } \\
\text { technology. } \\
\text { Lack non-verbal cues } \\
\text { Less improvisation }\end{array}$ & $\uparrow$ Instructional time \\
\hline Conclusion & $\begin{array}{l}\text { Online instruction is } \\
\text { more time consuming } \\
\text { and labor intensive } \\
\text { for faculty. }\end{array}$ & $\begin{array}{l}\text { Assuring appropriate } \\
\text { recognition for } \\
\text { distance learning } \\
\text { activities. }\end{array}$ & $\begin{array}{l}\text { Support for student } \\
\text { and faculty use of } \\
\text { information } \\
\text { technology is a } \\
\text { prerequisite for } \\
\text { successful distance } \\
\text { education. }\end{array}$ & \\
\hline
\end{tabular}

Current literature reporting outcomes associated with the use of distance learning in dental hygiene are consistent with the literature from other disciplines consisting of case descriptions, quantitative assessments comparing learner outcomes, and/or qualitative presentations of the experience of faculty or students. Findings from these investigations lend support to the premise the learning outcomes of distance dental hygiene students are similar to that of students who participated in the traditional classroom environment. An evaluation of the effectiveness of an online dental terminology course yielded no significant difference when comparing the final examination results between distance learners and traditional classroom students. ${ }^{9}$ A study comparing the performance of online and oncampus students in a nutrition class looked at not only course grades but also performance on the National Board Dental Hygiene Examination (NBDHE). A regression analysis was utilized to determine if age, grade point average (GPA), or course averages could be used to predict student performance on the NBDHE. GPA was in fact shown to be a weak indicator of course performance and NBDHE scores with correlation coefficients (0.291) and (0.074), respectively. ${ }^{10}$ No significant difference was reported regarding course average and NBDHE scores between online and on-campus students.

The relatively small numbers of dental hygiene students in a given class makes the accumulation of a meaningful sample size for analysis of distance learning outcomes problematic. The online dental terminology course consisted of only 14 students only four of which were dental hygiene students. The others were dental assisting students. Even when data is combined over subsequent years, as was the case for the nutrition course evaluation, the sample included only 30 students in the experimental group. The inherently small sample sizes of dental hygiene classes limits inference of results. 
Similar comparisons of GPA, course averages, and NBDHE results were reported for dental hygiene students in a distance learning program administered via interactive television (ITV). ${ }^{11}$ Northcentral Technical College in Wausau, Wisconsin, USA utilized two-way interactive video to deliver an entire didactic curriculum to three other schools at the time of publication two within Wisconsin and one school in central Kansas. The program began in 1993 in response to market demand for dental hygienists in the state of Wisconsin. Learner performance was compared for 221 students from five consecutive classes. Results indicate that distance students $(n=115)$ performed equally well on the NBDHE as did host (on-campus) students. While there was no statistically significant difference in NBDHE scores, the distance students' average was consistently higher than that reported for host students. Distance learners did not differ from their host student counterparts' performance in individual or cumulative course grades or GPA. A relatively strong correlation was found between GPA and NBDHE results for both distance and host students. Comparatively, a weak correlation was observed between age and GPA discarding the hypothesis that older students perform better in a distance environment.

\section{Dental Hygiene Educator Shortage}

The ability of distance education to provide instruction among geographically separated members of learning groups makes it a plausible solution to the shortage of not only clinicians but also educators in healthcare professions across the country. The issue of dental school faculty shortages has been well documented. ${ }^{12-15}$ Until recently, little was known regarding the status of dental hygiene and allied faculty shortages. A study conducted in 1996 showed $36 \%$ of dental hygiene program directors had a full-time faculty position vacancy at their institutions between 1994 and $1996 .{ }^{16}$ To further study the issue, the American Dental Education Association (ADEA) Board of Directors created the Task Force on the Status of Allied Dental Faculty, and a task force study was commissioned to investigate allied dental faculty shortages. An alarming 68\% reported the anticipated need to replace full-time faculty in the next five years. In terms of actual head count, this equals 196 full-time faculty vacancies. The authors attributed shortages to the small number of master's level programs in dental hygiene. ${ }^{17}$ Recommendations from the task force include investigating: the use of technology to maximize faculty resources, alternative ways to reward faculty, loan forgiveness incentives, establishment of a database to monitor the status of allied dental educators, and best practices to attract a diverse student body and faculty in terms of gender, ethnicity, and race.

\section{A Model Program}

One of the frequently cited advantages to distance delivery is the shift from instructor-centered to learner-centered instruction. This pedagogy is particularly well suited for advanced education where the faculties serve more as facilitators to the students' sampling and interpreting of new material. The opportunities afforded for degree advancement among place-bound individuals by distance learning is particularly advantageous to the dental hygiene profession. The majority of dental hygiene programs award an Associate Degree despite the matriculation of $90+$ credit hours by many students. Distance deliver offers graduate and degree completion students alike the opportunity to advance their academic degree without the need to relocate and while continuing to work.

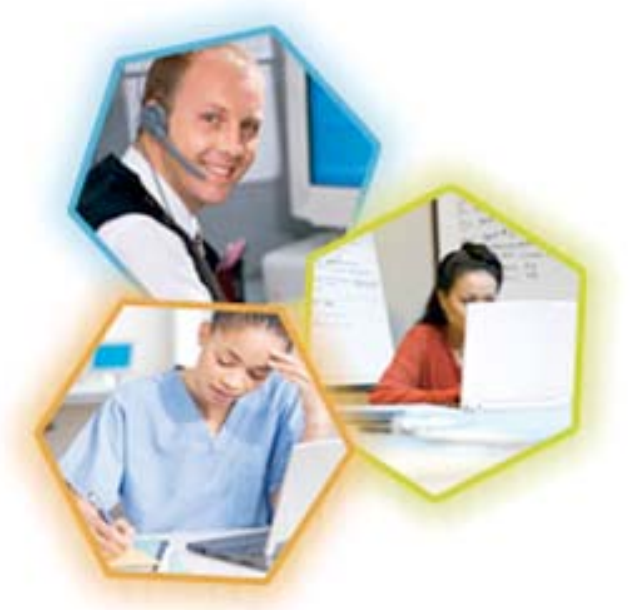

The graduate and degree completion programs at the University of Missouri-Kansas City (UMKC) Division of Dental Hygiene have prepared dental hygiene educators for more than three decades. Recently, UMKC has designed an option for the delivery of its graduate and degree completion programs via computer mediated distance learning. Preparing the student for advanced 
degrees in dental hygiene takes place utilizing a variety of asynchronous and synchronous learning including: mixed media, print-based, CD-ROM, web-based courses via Blackboard (Blackboard Inc., Washington, DC, USA) and internet-based formats such as chat rooms, bulletin boards, and email. Students are advised prior to being accepted into the programs about the expectations and requirements for successfully completing the curriculum. One of the requirements for students in both programs are personal visits to the UMKC campus approximately once per semester in fulfillment of course requirements. This differs from many distance education programs where student and faculty, as well as other enrolled students, may never meet. The face-to-face interaction, which occurs at these sessions, provides an opportunity for personal appraisal of the student progress toward program goals. Additionally, it is essential that both graduate and degree completion students liaison with a local/regional dental hygiene program to fulfill course requirements in Clinical and Classroom student teaching. Students initiate contact with local/regional dental hygiene programs to teach in their facility. The local dental hygiene affiliation may also provide mentorship and serve on the graduate student's research committee. Detailed programmatic information is available online at:

http://www.umkc.edu/dentistry/bec_student /MasterScienceDH.htm.

\section{Synchronous Instruction}

Periodic campus visits are not the only faceto-face interaction afforded by the distance deliver model developed at UMKC. One of the unique aspects of this distance model is the real time class sessions mediated through Centra One (Centra from Saba Redwood Shores, CA, USA), an electronic conference and symposia platform. Students and faculty are connected via web-camera video and live audio. Simultaneous utilization of a combination of presentation tools allows for the creation of a virtual classroom. Students login from their personal computer and are listed in the left hand column of the screen (Figure 1).

The toolbar allows students to symbolically respond to the lead presenter with a yes (green check mark), no (red X), laughter (blinking smiley face), or applause (clapping hands). A chronologic raised hand function allows the students to indicate their desire to engage in the session and the faculty to know which student to call on next. The large presentation window can be used to display a PowerPoint presentation or document, view a website, or conduct a survey. For example, in a graduate level Scientific Writing course the students research protocol documents can be viewed and co-edited by the lead presenter and the student with application sharing functions. The agenda function allows the lead presented to load such presentation materials in the appropriate sequence for easy access during the session. Additionally, a text chat tool allows students to post written feedback. Often the text chat appears to represent the side conversations students in a traditional classroom might have with each other such as confirming what a faculty has said or asking a peer if they can further explain a concept.

In addition to granting participants microphones for live audio interaction, Centra One allows for single live video imaging (Figure 2).

Typically the video is set for automatic switching and displays the image of the participant who is speaking. The platform allows for recording of the session for playback at the students discretion.

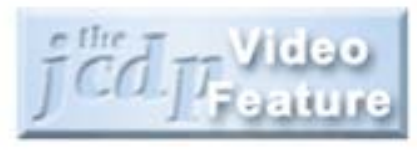

Go to the on-line article to view a recorded video clip of the software in use during a classroom session.

\section{Shortfalls and Limitations}

The development and implementation of this unique distance delivery model was not without shortfalls and limitations. One of the greatest shortfalls relates to the institution's general lack of an organizational structure for guiding the delivery of distance education. This is not unique to UMKC and has been widely reported in the academic literature. ${ }^{18-21}$ The institution provided the technology needed for the delivery of computer assisted instruction, however, the responsibility for seeking out available resources fell upon the faculty member who was ultimately responsible for the development and implementation of this 


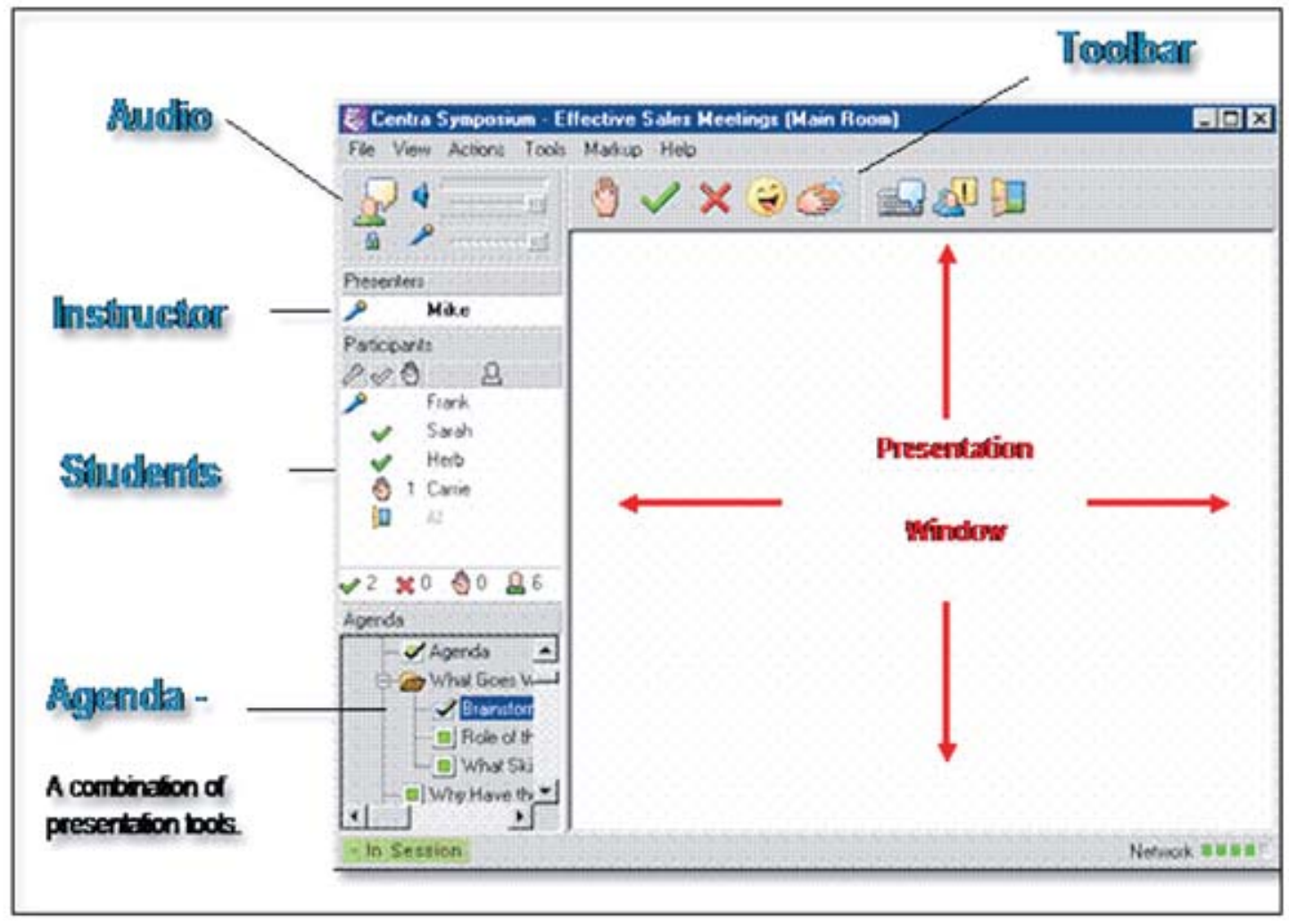

Figure 1. Centra One Electronic Classroom: Basic Functions.

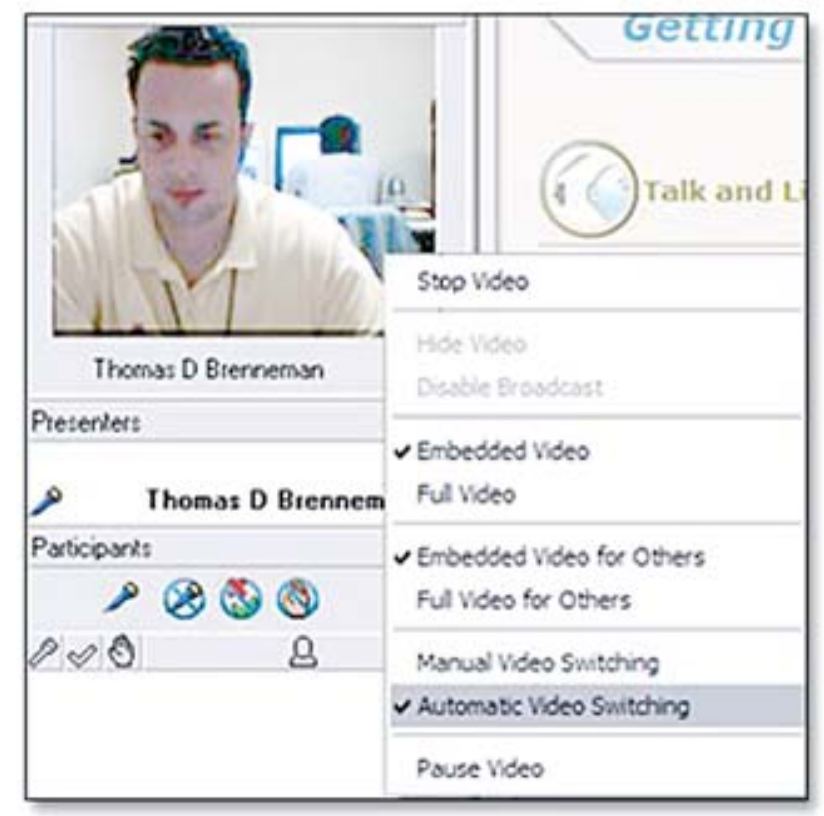

Figure 2. Webcam feed video of lead presenter in a synchronous classroom. 
model program. To add to that responsibility, it then became the faculty's sole responsibility to "ramp up" their knowledge and skills in technology in order to teach in a distance environment. Faculty in the division of dental hygiene had varying degrees of experience and comfort working with technology, so for some this involved a significant amount of time and energy. Fortunately, there were several innovative individuals on the campus willing to support our distance education efforts. The role of information support staff in providing the expertise and training needed to make this program a success was invaluable.

A lack of organizational structure also had an adverse effect on the distance students. Different support units of the campus such as library services, student services, or technology services were not accustomed to dealing with the unique needs of the distance student. Again, the responsibility fell on the program director and course directors to work with these various support services to help ensure the distance student needs could be met. Issues related to technology requirements, technology compatibility, and dealing with technology problems were mediated through the faculty member. It is easy to understand why the literature has reported over and over again the increased time needed to teach distance education courses, with this serving as one example that results in a significant time investment.
Much has been written about faculty perceptions regarding the lack of support from higher education administration when it comes to distance education. ${ }^{18,22}$ Our experience at UMKC was no different. To date there is no release time or additional compensation offered to faculty who develop and implement distance education courses. The frustration of faculty across the country who are early adopters of utilizing technology in the classroom and delivering distance education courses has been widely reported. ${ }^{23}$

\section{Enrollment Figures}

The applicant and enrollment figures for the distance and campus programs for the graduate and degree completion program are presented in Tables 2 and 3, respectively. A maximum of six graduate students (three campus/three distance and ten degree completion students (any combination of campus and distance) are enrolled each year. These data illustrate a clear trend in the demand for distance education surpassing the interest in the traditional campus based program. A comprehensive outcomes evaluation plan is being developed to measure student success in the distance option of these programs.

\section{Faculty Perceptions of Distance Learning} Only full-time tenured faculty members teach in the advanced education distance courses at UMKC. A qualitative survey was conducted to examine the perceptions of faculty providing

Table 2. Applicants and enrollment master of science in dental hygiene education.

\begin{tabular}{|l|c|c|c|c|c|c|c|}
\hline & 1999 & 2000 & 2001 & 2002 & 2003 & 2004 & 2005 \\
\hline $\begin{array}{l}\text { Total } \\
\text { applicants }\end{array}$ & 6 Campus & 2 Campus & $\begin{array}{l}\text { 7 Campus } \\
\text { 2 Distance }\end{array}$ & $\begin{array}{c}\text { 1 Campus } \\
\text { 2 Distance }\end{array}$ & $\begin{array}{c}\text { 2 Campus } \\
\text { 8 Distance }\end{array}$ & $\begin{array}{l}\text { 3 Campus } \\
\text { 6 Distance }\end{array}$ & $\begin{array}{c}\text { 4 Campus } \\
\text { 12 Distance }\end{array}$ \\
\hline Total enrolled & 3 Campus & 2 Campus & $\begin{array}{l}\text { 2 Campus } \\
\text { 2 Distance }\end{array}$ & $\begin{array}{l}\text { 1 Campus } \\
\text { 2 Distance }\end{array}$ & $\begin{array}{l}\text { 2 Campus } \\
\text { 4 Distance }\end{array}$ & $\begin{array}{l}\text { 3 Campus } \\
\text { 3 Distance }\end{array}$ & $\begin{array}{l}\text { 3 Campus } \\
\text { 3 Distance }\end{array}$ \\
\hline
\end{tabular}

Table 3. Applicant and enrollment degree completion.

\begin{tabular}{|l|c|c|c|c|c|c|c|}
\hline Entering Enrollment Date & 1999 & 2000 & 2001 & 2002 & \multicolumn{1}{|c|}{2003} & \multicolumn{1}{c|}{2004} & \multicolumn{1}{c|}{2005} \\
\hline Total applicants interviewed & & $\begin{array}{l}\text { 5 Campus } \\
\text { 1 Distance }\end{array}$ & $\begin{array}{l}\text { 2 Campus } \\
\text { 1 Distance }\end{array}$ & 2 Campus & $\begin{array}{l}\text { 4 Campus } \\
\text { 6 Distance }\end{array}$ & $\begin{array}{l}\text { 1 Campus } \\
\text { 3 Distance }\end{array}$ & $\begin{array}{l}4 \text { Campus } \\
7 \text { Distance }\end{array}$ \\
\hline Total enrollment & 3 Campus & $\begin{array}{l}\text { 3 Campus } \\
\text { 1 Distance }\end{array}$ & $\begin{array}{l}\text { 2 Campus } \\
\text { 1 Distance }\end{array}$ & 2 Campus & $\begin{array}{l}\text { 2 Campus } \\
\text { 5 Distance }\end{array}$ & $\begin{array}{l}\text { 1 Campus } \\
\text { 2 Distance }\end{array}$ & $\begin{array}{l}\text { 4 Campus } \\
\text { 4 Distance }\end{array}$ \\
\hline
\end{tabular}


computer-mediated courses. When asked to describe the instructional quality of their courses, the following comments were generated: "It is well documented in the literature that distance education does not negatively impact outcomes. I feel...students do make a compromise in personal interaction for their program of study....but gain...the ability to earn their degree without...giving up their current positions." Another faculty member commented adapting to technology "is always a learning curve for students...so...I facilitate the course by helping the students become comfortable with the technology."

\section{Student Perceptions of Distance Learning} Both current and past students in both distance programs seem happy in their choice in continuing their education via distance learning at UMKC. This is evident as one student was "impressed with the program's 'custom-fit' curriculum...flexibility to tailor it to my needs and career aspirations." This same student found it "...was extremely rewarding to present a project I had been building on all semester. It was also great fun to meet...my classmates in person." These findings support the conclusions of Grimes9 who found students' overall perceptions of online learning were positive. She reported students found it easy to access an online dental terminology course and favorable to complete required coursework at a time that was wellmatched with work and family schedules.

\section{Conclusion}

The last decade has provided steady growth in distance education course offerings and enrollment. Online learners represent a

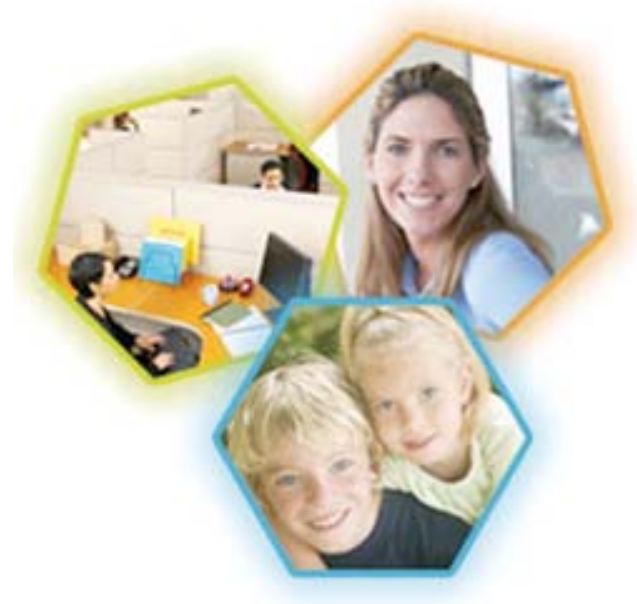

distinct student population whose work and/ or family circumstances preclude traditional college attendance. The 1999-2000 National Postsecondary Student Aid Study (NPSAS 2000) describes the profile of distance learners. ${ }^{3}$ Limited time is a characteristic shared by distance learners who are more likely to be enrolled part-time while working full-time. More specifically, undergraduates who were older, female, financially independent, married, or had dependent children were more likely to participate in distance education. Similar patterns were observed among graduate students with gender differences undetected.

Trends in enrollment data suggest distance education is growing and likely here to stay. Distance learning provides a means to meet the unique demands of learners challenged by multiple demands on their time. While the technology provides the opportunity, there is still much to be done to determine the most effective means and the outcomes of distance instruction. 


\section{References}

1. Oblinger, Diana G. Barone, Carole A. Hawkins, Brian L: Distributed Education and Its Challenges: An Overview. Distributed Education: Challenges, Choices, and a New Environment. American Council on Education, Washington, DC. Center for Policy Analysis Washington, DC; 2001.

2. Moore MG, Kersley G. Distance Education: A systems view. Belmont CA: Wadsworth Publishing Co; 1996.

3. Sikora A. A profile of participation in distance education: 1999-2000 postsecondary descriptive analysis reports. ED pubs 2002.

4. National Center for Education Statistics of the US Department of Education. Distance Education at Postsecondary Education Institutions 1997-98. CHEA Update 1999;3.

5. Cravener PA. Faculty experiences with providing online courses thorns among the roses. Computers in Nursing 1999;17:42-47.

6. Oblinger, DG, Oblinger JL. Educating the net generation. Educause ebook, 2005.

7. Billings DM. Teaching and learning at a distance: a review of the literature in Allen LR(ed):Review of research in nursing education. New York, NY, National League of Nursing, 1995:1-32.

8. Billings DM. A framework for assessing outcomes and practices in web-based courses in nursing. J Nurs Educ 2000;39:60-67.

9. Grimes EB. Effectiveness of an online course in dental terminology. J Dent Ed 2001;65:242-7.

10. Bearden EB, Robinson K, Deis MH. A statistical analysis of dental hygiene students grades in online and on campus curses and performance on the National Board Dental Hygiene Exams. J Dent Hygiene 2002;76:213-217.

11. Olmsted JL. Longitudinal analysis of student performance in a dental hygiene distance program. J Dent Ed 2002;66:1012-20.

12. Future of dental school faculty: report of the president's task force. Washington, DC: American Association of Dental Schools, 1999.

13. Haden NK, Beemsterboer PL, Weaver RG, Valachovic RW. Dental school faculty shortages increase: an update on future dental school faculty. J Dent Ed 2000;64: 657-73.

14. Weaver RG. Haden NK. Valachovic RW. Dental school vacant budgeted faculty positions: academic year 2000 - 2001. J Dent Ed 2001; 65:1291-302.

15. Haden NK, Weaver RG, Vallacovic RW. Meeting the demands for future dental school faculty: trends, challenges and responses. J Dent Ed 2002;66:1102-13.

16. Wilder RS, Mann G, Tishk M. Dental hygiene directors' perceptions of graduate dental hygiene education and future faculty needs. J Dent Ed 1999;63:479-88.

17. Nunn PJ, Gadbury-Amyot CC, Battrell A, Bruce SI, Hanlon LL, Kaiser C, Purifoy-Seldon B. The current status of Allied Dental Faculty: A survey report. J. Dent. Ed. 2004; 68: 329-344.

18. Andrews KG, Demps EL. Distance education in the U.S. and Canadian undergraduate dental curriculum. J Dent Educ. 2003 Apr;67(4):427-38.

19. Duin AH, Poley J, Baer LL, Langer G, Pickett J. Moving forward with distance education. Business Officer, 2002 35(11):18-23.

20. Hignite K. E-Learning's impact on the campus bottom line. Business Officer, 2002 36(5): 22-23.

21. Broskoske SL, Harvey FA. (2000). Challenges faced by institutions of higher education in migrating to distance learning. Research report. In: Annual proceedings of selected research and development papers presented at the National Convention of the Association for Educational Communications and Technolgoy (23rd, Denver, CO, October 25-28, 2000). Volumes 1-2.

22. Betts KS (1998). Factors influencing faculty participation in distance education in post secondary institutions in the United States: An institutional study. (Doctoral dissertation, The George Washington University). Dissertation Abstracts International: UMI.

23. Carnevale D. (2004). Chronicle of Higher Education. From the issue dated August 13, 2004. Accessed online. 

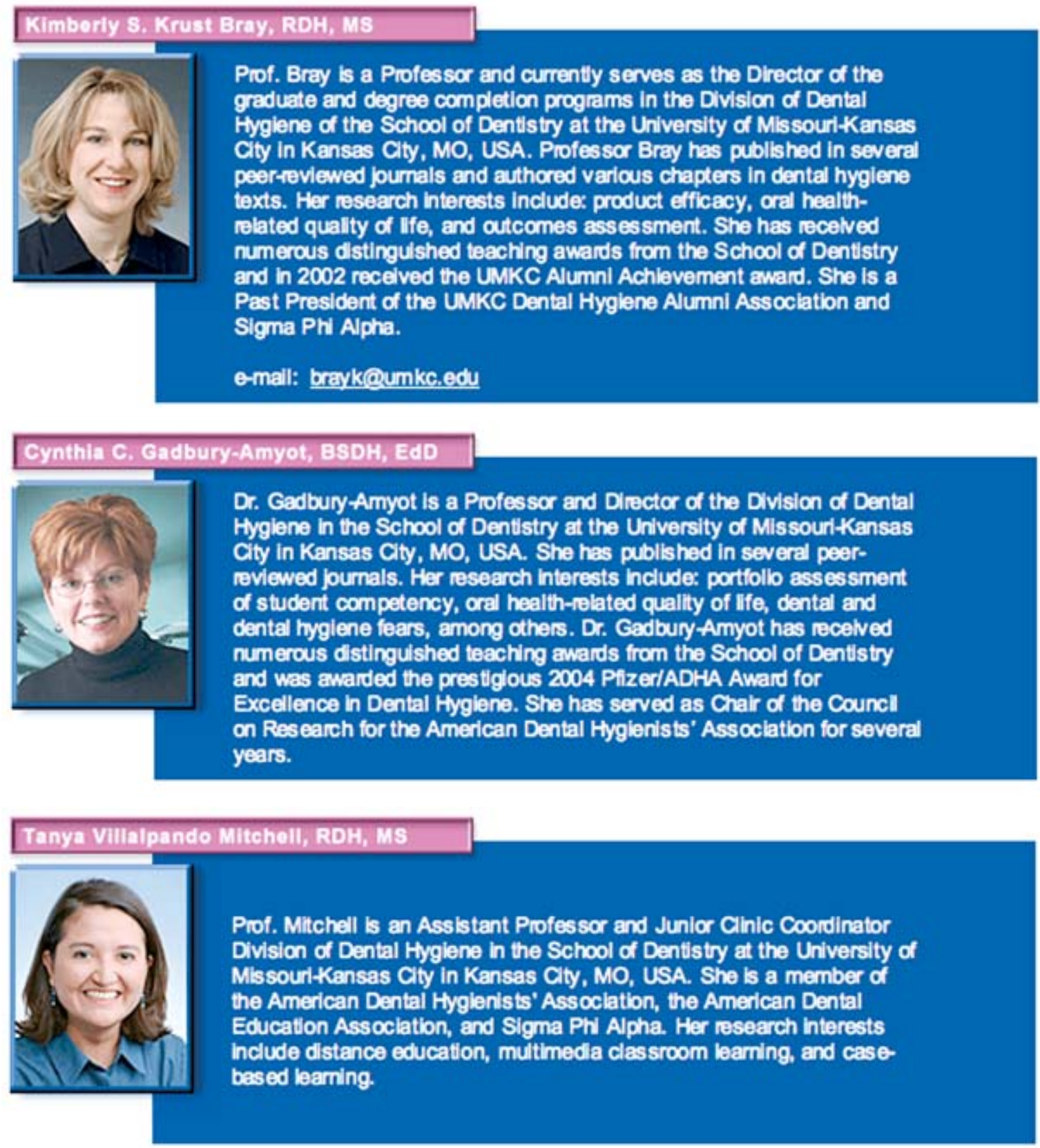

\section{Acknowledgements}

The authors wish to thank: the Faculty in the Division of Dental Hygiene for supporting the distance delivery option; Dr. Cindy Amyot for the conceptualization and development of the distance delivery programs; Dr. Pam Overman for providing the administrative support; David Anstaett, Tom Brenneman, and Tony Schutz at the Technology for Teaching and Learning Center for providing the technical support behind the course offerings. 